\title{
Upaya Penanggulangan Banjir dengan Menerapkan Beton Non Pasir Untuk Sumur Resapan di RT. 04/RW. 02 Kelurahan Beji Timur Depok
}

\author{
Flood Prevention by Applying Non-Sand Concrete for Infiltration Wells in RT. 04/RW. 02 \\ Kelurahan Beji Timur Depok
}

\author{
Yelvi ${ }^{1 *}$, Anni Susilowati ${ }^{1}$, Mochammad Sholeh ${ }^{1}$ \\ ${ }^{1}$ Politeknik Negeri Jakarta \\ *yelvi@sipil.pnj.ac.id
}

\begin{abstract}
ABSTRAK
Kelurahan Beji Timur memiliki wilayah topografi dataran rendah bergelombang dengan kemiringan sampai $20 \%$, sehingga terdapat daerah cekungan. Jika intensitas hujan cukup tinggi, daerah cekungan ini sering kebanjiran. Penyebabnya antara lain adanya kiriman air dari daerah yang lebih tinggi. Sementara tanah sebagai peresapan air banyak yang sudah tertutupi oleh beton dan aspal akibat semakin padatnya pemukiman penduduk. Air dalam jumlah yang banyak dan deras yang tidak bisa tertampung lagi oleh drainase menggenang dan mengakibatkan banjir dan hal ini terjadi setiap tahun. Tentu saja banjir sangat merugikan bagi masyarakat yang bermukim di daerah itu. Tim Pengabdian Kepada Masyarakat (PKM) mencoba berpartisipasi menanggulangi banjir dengan membuat sumur resapan. Sumur resapan memberikan banyak keuntungan antara lain mengurangi aliran permukaan dan mencegah terjadinya genangan air, mempertahankan tinggi muka air tanah dan menambah persediaan air tanah. Sumur resapan ini menggunakan material beton non pasir yang merupakan inovasi teknologi beton ringan. Beton non pasir yang bersifat mudah dilalui air karena tidak menggunakan agregat halus (pasir) sangat cocok digunakan sebagai material untuk sumur resapan. Sumur resapan yang akan dibuat sebanyak 3 (tiga) buah dan mempunyai diameter $100 \mathrm{~cm}$. Lokasi yang dipilih untuk penempatannya adalah daerah yang lebih tinggi dari daerah cekungan, dan merupakan daerah tangkapan hujan yaitu RT 04/RW 02 Kelurahan Beji Timur. Sehingga dengan dibuatnya sumur resapan diharapkan dapat mencegah terjadinya banjir dan dapat menjaga persediaan air tanah pada waktu musim kemarau.
\end{abstract}

Kata kunci — beton non pasir, sumur resapan, banjir

\begin{abstract}
East Beji Village has a undulating lowland topography area with a slope of up to $20 \%$, so there is a basin area. If the rainfall intensity is high enough, this basin area is often flooded. The reason is, among others, the delivery of water from higher areas. Meanwhile, the land as water absorption has been covered by concrete and asphalt due to the increasingly dense population. The large and heavy amount of water that can no longer be accommodated by the drainage pools and causes flooding and this happens every year. Of course, flooding is very detrimental to the people who live in the area. The Community Service Team (PKM) tried to participate in tackling flooding by building infiltration wells. Infiltration wells provide many advantages, including reducing runoff and preventing waterlogging, maintaining groundwater levels and increasing groundwater supplies. This infiltration well uses non-sand concrete material which is an innovative lightweight concrete technology. Non-sand concrete which is easy to pass water because it does not use fine aggregate (sand) is very suitable to be used as material for infiltration wells. There will be 3 (three) infiltration wells and have a diameter of $100 \mathrm{~cm}$. The location chosen for its placement is an area that is higher than the basin area, and is a rain catchment area, namely RT 04/RW 02, Beji Timur Village. So that by making infiltration wells it is hoped that it can prevent flooding and can maintain ground water supplies during the dry season.
\end{abstract}

Keywords - non-sand concrete, infiltration well, flood 


\section{Pendahuluan}

Kelurahan Beji Timur merupakan salah satu Kelurahan yang ada di Kecamatan Beji Kota Depok yang terbentuk berdasarkan Surat Keputusan Menteri Dalam Negeri Nomor 146.1/4024/PUOD/94 tanggal 03 November 1994, tentang Perubahan Status Desa menjadi Kelurahan dan diperkuat dengan UndangUndang Nomor 15 tahun 1999, tentang Pembentukan Kotamadya Daerah Tingkat II Cilegon dan Kotamadya Daerah Tingkat II Depok tanggal 27 April 1999 [1]. Kelurahan Beji Timur memiliki wilayah seluas 100,7 hektar dengan rincian sebagai berikut :

- 90,3 hektar sebagai daerah pemukiman

- 1,3 hektar sebagai tanah makam

- 5,85 hektar sebagai taman

- 0,05 hektar sebagai perkantoran

- 3,2 hektar sebagai prasarana umum lainnya.

Kelurahan Beji Timur terletak di daerah dataran rendah dengan ketinggian 1.500 meter di atas permukaan air laut. [1]

Pada awal sebelum berdirinya Universitas Indonesia di Depok, Kelurahan Beji Timur masih merupakan lahan perkebunan dan empang milik warga setempat dan sebagian besar tidak bertuan (milik negara). Ketika pada akhirnya proyek pembangunan Universitas Indonesia di Depok dilaksanakan, maka sebagai kompensasi penggantian atas lahan warga yang terkena proyek tersebut diberikanlah sejumlah uang dan lahan kavling di daerah kelurahan Beji Timur ini [2].

Lahan penggantian di daerah Beji Timur ini tertata dalam blok-blok dan kapling-kapling yang cukup rapi dengan luas lahan per kaplingnya kurang lebih $500 \mathrm{~m}^{2}$. Karena itu, sampai sekarang ini, kelurahan Beji Timur lebih dikenal oleh warga setempat dengan nama "Tanah Kapling". Untuk kelengkapan daerah Kelurahan Beji Timur, pemerintah juga menyediakan fasum berupa satu lapangan bola, satu sekolahan, satu puskesmas, satu posyandu dan satu mesjid. Bahkan saat ini tempat tersebut sudah sedemikian berkembangnya sehingga telah berdiri bangunan fasum yang baru berupa gereja, mesjid dan beberapa sekolah swasta [2].
Berdasarkan deskripsi di atas, Kelurahan Beji Timur merupakan daerah perkotaan yang cukup padat penduduknya, dan akan terus berkembang dengan adanya jalan tol DepokAntasari (Desari) yang membentang antara Kel. Beji Timur dengan lingkungan Kampus UI dan PNJ.

Semakin berkembangnya suatu daerah, akan ada beberapa masalah yang akan timbul. Masalah tersebut harus ditanggulangi sedini mungkin sehingga tidak berlarut-larut terjadi. Salah satu masalah yang timbul di daerah Kelurahan Beji Timur adalah banjir. Kondisi topografi wilayah kelurahan Beji Timur berupa dataran rendah bergelombang dan mempunya kemiringan sampai $20 \%$ menyebabkan masalah banjir di beberapa wilayah, terutama di daerah cekungan. Kondisi ini diperparah dengan adanya sungai yang melintasi daerah cekungan, sehingga jika hujan turun selama lebih kurang 1 (satu) jam kawasan tersebut akan terkena banjir. Banjir sudah menjadi langganan yang datang setiap tahun di kawasan ini. Masalah ini tentu saja tidak bisa dibiarkan terjadi terus menerus, karena akan menimbulkan kerugian bagi masyarakat dan lingkungan di sekitarnya. Kerja sama dari semua pihak yaitu masyarakat, pemerintah, serta perhatian dari perguruan tinggi yang terdekat seperti UI dan PNJ sangat diperlukan.

Banjir dapat disebabkan oleh ketersediaan tanah yang semakin berkurang untuk penyerapan air. Pertumbuhan penduduk yang semakin padat menyebabkan tanah banyak dijadikan perumahan, pembangunan jalan, dan fasilitas umum yang menyebabkan tanah banyak ditutupi oleh aspal dan beton seperti ditunjukkan pada Gambar 1.1.

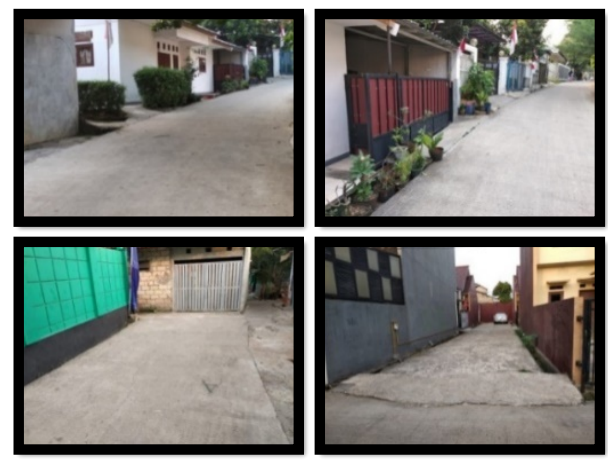

Gambar 1. Lingkungan Perumahan di RT. 04/RW. 02 
Ditambah lagi kebanyakan penduduk menyukai halaman rumahnya dilapisi keramik karena terlihat lebih bersih. Sehingga pada waktu hujan turun tanah tidak dapat menyerap air. Sifat air yang selalu mengalir menuju tempat yang lebih rendah menyebabkan daerah yang berada di cekungan mendapat kiriman air dari daerah di atasnya. Air dalam jumlah yang banyak dan deras yang tidak bisa tertampung lagi oleh saluran-saluran pun menggenang dan mengakibatkan banjir.

Penduduk setempat sangat mengharapkan perhatian dari pemerintah kota dalam mengatasi banjir ini. Hal ini tentu saja tidak cukup hanya mengandalkan pemerintah saja, dibutuhkan juga kesadaran masyarakat dalam menjaga lingkungannya. Pada tahun 2005 pemerintah kota Depok melalui kelurahan memberikan bantuan berupa pembuatan sumur resapan sebagai salah satu upaya dalam menanggulangi bencana banjir yang ditempatkan di fasum. Salah satunya ditempatkan di area musholla RW. 02 sebanyak dua buah. Menurut masyarakat setempat, pada saat ini sumur tersebut tinggal satu karena yang satu lagi tidak ditemukan keberadaannya. Sejak tahun 2007 oleh masyarakat sumur resapan yang satu lagi diubah fungsinya sebagai tempat untuk menampung buangan air wudhu. Sehingga sampai saat ini air di musholla tersebut tidak pernah kering.

Masalah lain yang muncul di perkotaan selain banjir adalah penurunan muka air tanah akibat kebutuhan air yang semakin meningkat karena pertambahan penduduk. Tentu saja hal ini tidak dapat dibiarkan, harus dipikirkan bagaimana cara menanggulangi. Tim Program Kemitraan Masyarakat (PKM) yang berada dalam naungan Politeknik Negeri Jakarta (PNJ) dan merupakan salah satu Perguruan Tinggi yang terdekat dengan Kelurahan Beji Timur, mencoba berpartisipasi dalam mengatasi masalah banjir ini. Tim PKM mempelajari situasi lingkungan yang ada dan mengambil keputusan untuk membuat sumur resapan di daerah yang berada di atas daerah cekungan. Berhubung Kelurahan Beji Timur cukup luas, sehingga kegiatan ini hanya dilakukan di lingkungan RT 04 RW 02. (Gambar 1.2.) yang lokasinya berada diatas daerah cekungan.

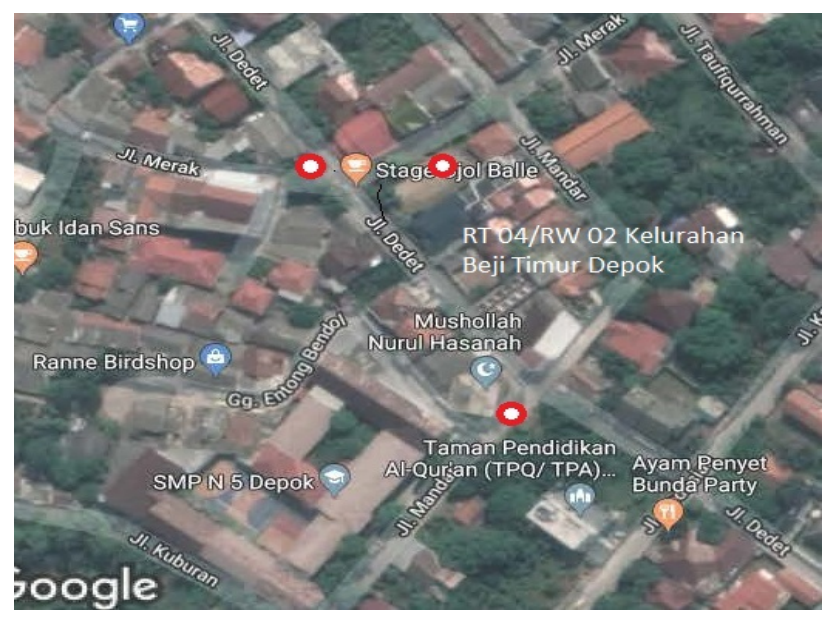

Gambar 2. Lokasi PKM di RT. 04/RW. 02

Sumur resapan merupakan suatu sistem resapan dengan jalan menampung air hujan yang jatuh di atap atau lahan yang kedap air untuk meresap ke dalam tanah [3]. Di sisi lain menurut Arafat (2008), prinsip dasar sumur resapan adalah menyalurkan dan menampung curah hujan ke dalam sebuah sumur dengan tujuan agar air hujan memiliki waktu tinggal di permukaan tanah lebih lama sehingga sedikit demi sedikit air dapat meresap ke dalam tanah [4]. Selain itu sumur resapan berguna sebagai salah satu cara dalam meningkatkan volume air tanah dan upaya penanggulangan dampak bencana alam kekeringan [5]. Teknik konservasi tanah dan air dengan menggunakan metode sumur ini dapat mengendalikan dampak dari air hujan dengan meresapkannya ke dalam tanah sehingga air tidak banyak terbuang sebagai aliran permukaan, menjaga cadangan air tanah, dan menjaga pemukiman agar tidak tergenang [6].

Pada pembuatan sumur resapan ada beberapa hal yang harus diperhitungkan yaitu, iklim, kondisi air tanah, tata guna lahan, dan kondisi sosial masyarakat [7]. Mulyana (1998) juga menyebutkan bahwa kondisi permukaan air tanah dan kondisi tanah sangat berpengaruh pada besar kecilnya daya resap tanah terhadap air hujan [8].

Sumur resapan yang akan dibuat dalam pengabdian ini adalah dari beton non pasir. Beton non-pasir (no fines concrete) ialah suatu bentuk sederhana dari jenis beton ringan yang dalam pembuatannya tidak dengan agregat halus. Tidak adanya agregat halus dalam campuran menghasilkan beton yang berpori (yang semula diisi agregat halus) sehingga beratnya berkurang. 
Pori-pori di dalam beton tersebut mencapai sekitar 20 sampai 25 persen [9]. Biasanya, beton Non Pasir memiliki kuat tekan sebesar 2,8 - 28 $\mathrm{MPa}$ (menurut ACI 522R Report On Pervious Concrete) menjadikan beton non pasir lebih cocok bila diaplikasikan sebagai area tempat parkir, jalan taman, sidewalk, trotoar, atau jalanan di perumahan dengan intensitas kendaraan yang kecil [10]. Menurut Kardiyono dalam buku Teknologi Beton beton non pasir dapat digunakan untuk sumur resapan [9].

Berdasarkan syarat dan ketentuan dalam membuat sumur resapan, maka pada kegiatan ini Tim PKM menentukan lokasi penempatan sumur resapan dipilih di daerah tangkapan hujan yaitu daerah sebelah atas dari cekungan. Hal ini dilatarbelakangi dari jenis tanah di daerah tersebut yaitu tanah berbutir halus (lempung). Berbeda dengan jenis tanah pasir, tanah ini tidak mudah untuk dilalui air. Akibatnya jika ada genangan air, air membutuhkan waktu yang lama terserap ke dalam tanah. Apabila ditempatkan di daerah cekungan akan kurang efektif, karena air dalam sumur resapan lama terserap oleh tanah, sementara air kiriman dari daerah sebelah atas semakin banyak dan tidak tertampung lagi oleh sumur resapan. Tim PKM berharap sumur resapan yang terbuat dari beton non pasir ini dapat mengatasi masalah banjir pada musim hujan dan dapat menjaga ketersediaan air tanah pada waktu musim kemarau.

\section{Target dan Luaran}

Target luaran yang diharapkan dari kegiatan PKM ini adalah :

a. Teknologi Tepat Guna berupa Metode dan Produk

Metode : Masyarakat mengetahui dan mendapatkan informasi serta skill tentang Pelaksanaan Pembuatan Sumur Resapan dan pemeliharaannya secara berkala.

Produk: Masyarakat dapat membuat sumur resapan secara bergotong royong menggunakan beton non pasir.

b. Meningkatkan pemahaman masyarakat RT 04/RW 02 Kelurahan Beji Timur Depok dalam pembuatan sumur resapan sebagai upaya penanggulangan banjir dan sebagai resapan air tanah.

c. Keberadaan Politeknik Negeri Jakarta sebagai salah satu Perguruan Tinggi yang berada dekat dengan Kelurahan Beji Timur Depok dapat dirasakan manfaatnya secara nyata bagi masyarakat sekitarnya.

d. Publikasi pada Media Cetak, yang sudah terbit pada media cetak Radar Depok pada tanggal 29 Juli 2019

e. Dokumentasi pelaksanaan kegiatan yang sudah diunggah di Youtube dengan link: https://m.youtube.com/watch?v=wTOdXVn4 S-g

f. Publikasi Artikel Ilmiah

\section{Metodologi}

3.1. Metode

Metode Pendekatan dan Langkah-Langkah Pelaksanaan Solusi

Untuk terlaksananya kegiatan Program Kemitraan Masyarakat ini, dilakukan langkahlangkah sebagai berikut :

a. Studi literatur mengenai materi yang berkaitan dengan usulan Pengabdian pada masyarakat tentang "Upaya Penanggulangan Banjir dengan Menerapkan Beton Non Pasir untuk Sumur Resapan Di RT. 04/RW. 02 Kelurahan Beji Timur Depok'

b. Melakukan survey lapangan. Survei ini dilakukan untuk mendapatkan data yang relevan dengan kegiatan ini. Adapun data dikumpulkan melalui :

- Wawancara, untuk mendapatkan data dari beberapa masyarakat dan Ketua RT 04/RW 02 Kelurahan Beji Timur Depok. Dari wawancara tersebut diperoleh informasi bahwa jika hujan turun selama dua jam saja lokasi yang cukup rendah akan kebanjiran. Kemudian pada waktu musim kemarau sumur warga menjadi kering. Resapan air ke dalam tanah semakin berkurang karena perumahan penduduk semakin padat.

- Observasi lapangan. Dengan melakukan pengamatan langsung melihat kondisi lingkungan di RT 04 RW 02 Kelurahan Beji Timur Depok. Warga masyarakat 
sangat antusias dan mendukung kegiatan ini dapat segera terwujud.

c. Melakukan diskusi sesama tim juga diskusi dengan tim pengarah dari lembaga pengabdian.

d. Pembuatan sumur resapan dilakukan dalam beberapa tahap yaitu pembuatan cetakan buis beton (beton non pasir), pengecoran buis beton (beton non pasir) serta tutupnya, penggalian tanah, pemasangan buis beton, pembuatan saluran air, pengisian buis beton dengan batu dan ijuk, pemasangan tutup sumur resapan. Untuk lebih jelasnya metode pelaksanaan akan dijelaskan sebagai berikut.

\subsubsection{Pembuatan Cetakan Buis Beton dan Tutupnya}

Cetakan sumur resapan berbentuk buis beton rencananya dibuat di bengkel Jurusan Teknik Mesin PNJ. Namun karena bertepatan dengan adanya praktik mahasiswa, akhirnya dibuat oleh pihak lain sesuai dengan desain yang sudah direncanakan. Terbuat dari pelat baja berbentuk silinder yang didesain dua buah, yaitu silinder bagian luar dan dalam. Ukuran bagian luar adalah 1,2 $\mathrm{m}$ dan bagian dalam 1,0 $\mathrm{m}$ dengan tinggi $0,5 \mathrm{~m}$. Pelat silinder tersebut dibuat sedemikian rupa menggunakan klem untuk memudahkan cetakan dilepas. Cetakan untuk tutup dibuat dengan ukuran $0,08 \mathrm{~m}$ x $0.6 \mathrm{~m}$ x 1,2 m. Untuk lebih jelasnya dapat dilihat pada Gambar 3.1.
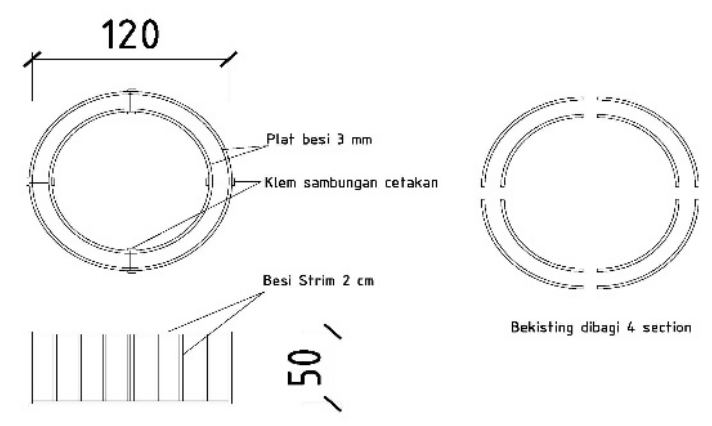

Gambar 3. Cetakan (bekisting) buis beton

\subsubsection{Pengecoran Buis Beton (Beton Non Pasir) dan Tutup}

Pengecoran buis beton dan tutupnya dilakukan di laboratorium Jurusan Teknik Sipil
PNJ. Komposisi beton non pasir yang digunakan sesuai dengan hasil penelitian yaitu 1 semen : 4 agregat kasar dengan faktor air semen 0,4. Bahan disiapkan sesuai dengan volume untuk satu buah buis beton dan tutup. Sesudah bahan disiapkan diaduk menggunakan molen. Kemudian dimasukkan ke dalam cetakan dan didiamkan selama 24 jam. Keesokan harinya cetakan dilepas dan dilakukan perawatan beton (curing) dengan disiram air atau ditutupi dengan karung basah. (Gambar 3.2)

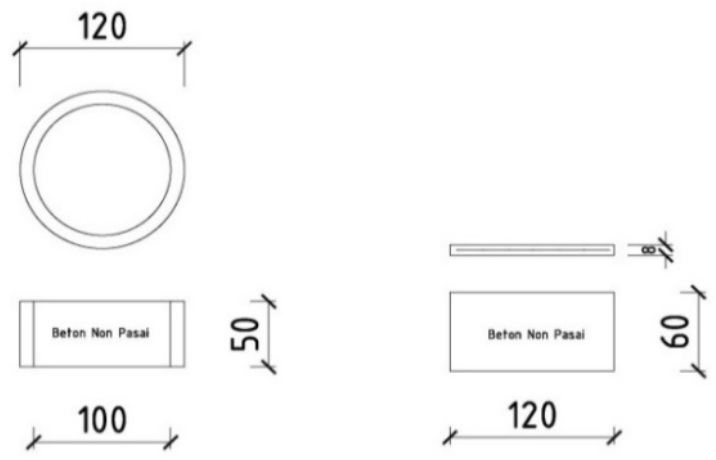

Gambar 4. Buis beton dan tutupnya

\subsubsection{Penggalian Tanah dan Pemasangan Buis Beton di Lokasi}

Galian tanah untuk pemasangan buis beton direncanakan setinggi $2 \mathrm{~m}$. Penggalian dilakukan di titik yang sudah direncanakan letak sumur resapan. Penggali berdiri dititik yang sudah ditentukan dimana penggali berada di dalam buis beton yang diletakkan di atas permukaan tanah. Galian tanah dilakukan sampai kedalaman $2 \mathrm{~m}$,

\subsubsection{Pengisian Pecahan Batu dan Ijuk}

Pada dasar sumur resapan diisi dengan pecahan batu berukuran $20-30 \mathrm{~cm}$, lalu tutup dengan ijuk. Fungsi ijuk dan batu-batuan yang diletakkan di bagian dasar sumur resapan yaitu sebagai penyaring kotoran yang ikut mengalir bersama air hujan, sehingga kotoran tersebut tidak ikut masuk ke dalam tanah (Gambar 3.5). 


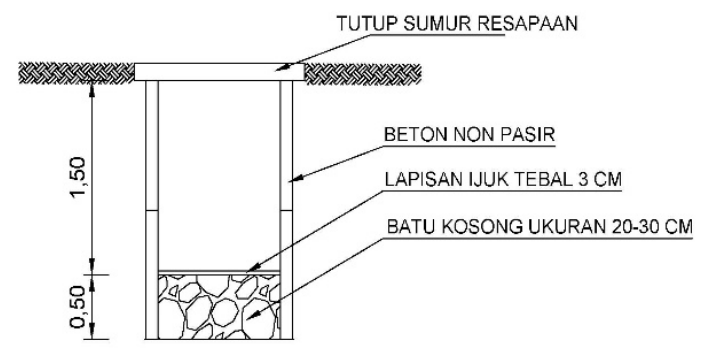

Gambar 5. Penggalian tanah dan pengisian pecahan batu dan ijuk

\subsubsection{Pembuatan Saluran Air}

Saluran air gunanya untuk menghubungkan drainase dari rumah penduduk ke sumur resapan Oleh sebab itu dilakukan galian tanah dangkal dari drainase ke sumur resapan. Saluran dibuat dari pipa paralon ukuran $110 \mathrm{~mm}$.

\subsubsection{Pemasangan Tutup Sumur Resapan}

Bagian atas sumur resapan ditutup dengan plat beton bertulang dengan tebal $0,08 \mathrm{~m}$. Selain itu, bisa juga digunakan plat beton tidak bertulang sebagai tutup sumur resapan, dengan bentuk cubung. Tidak boleh diberikan beban di atasnya, sedangkan ketebalan dan perbandingan bahan campurannya sama dengan tutup sumur resapan dari plat beton bertulang. Ferrocement setebal $10 \mathrm{~cm}$ juga bisa dijadikan alternatif lain yang bisa dijadikan tutup sumur resapan.

Demikianlah tahap pembuatan sumur resapan yang akan dilakukan di lingkungan RT. 04/RW. 02 Kelurahan Beji Timur, Kecamatan Beji Kota Depok.

\subsection{Partisipasi Mitra}

Untuk menunjang Pelaksanaan Program Kemitraan Masyarakat ini, maka diharapkan partisipasi dan keikutsertaan mitra sehingga program ini dapat berjalan dengan lancar, yang mana partisipasi mitra antara lain :

a. Ikut berpartisipasi aktif dalam memberi masukan lokasi penempatan sumur resapan. Kegiatan ini dapat menambah wawasan pada masyarakat yang alamiah menjadi ilmu pengetahuan dan teknologi dalam mengatasi persoalan lingkungan yang dihadapi.

b. Memberikan dukungan secara bergotong royong dengan tim pelaksana melakukan pembuatan sumur resapan. c. Memberikan informasi tentang hasil dari pembuatan sumur resapan, apakah sudah ada pengaruhnya pada saat musim hujan dan kemarau.

\subsection{Evaluasi Program}

Metode evaluasi yang diterapkan dalam program ini adalah :

a. Dapat dilihat dari seberapa besar antusias masyarakat RT 04 RW 02 Kelurahan Beji Timur Depok dalam kesediaan mereka menyediakan lahan untuk sumur resapan.

b. Dapat dilihat dari keikutsertaan masyarakat pada waktu pelaksanaan pembuatan sumur resapan.

\subsection{Keberlanjutan Program}

Keberlanjutan Program yaitu : Dapat dilihat dari keinginan masyarakat yang ada di sekitar untuk mengikuti RT 04 RW 02 Kelurahan Beji Timur Depok dalam membuat sumur resapan dilingkungan mereka, mengingat topografinya sama sehingga permasalahannya pun hampir sama.

\section{Pembahasan}

Hasil yang dicapai dapat dijelaskan sebagai berikut :

a. Pada bulan April 2019 Tim PKM berkunjung ke lokasi penelitian untuk membicarakan lokasi pembuatan sumur resapan. Pertemuan dilakukan dengan beberapa warga dan Ketua RT 04/RW 02. Sumur resapan akan dibuat tiga buah, dengan lokasi yang ditentukan yaitu di depan balai karya, taman, dan musholla. Tim PKM menjelaskan kepada warga tahaptahap pelaksanaan dalam pembuatan sumur resapan.

b. Pembuatan cetakan dimulai pada Bulan Mei 2019. Cetakan buis beton dibuat dari pelat baja dengan diameter luar $120 \mathrm{~cm}$, diameter dalam $100 \mathrm{~cm}$ dan tinggi $50 \mathrm{~cm}$. Cetakan buis beton selesai dan diserahkan kepada Tim PKM pada tanggal 17 Mei 2019. Proses pengerjaannya dapat dilihat pada Gambar 6 .

c. Pada tanggal 16 Juni 2019 pembuatan buis beton dimulai. Sumur resapan yang akan dibuat dalamnya $2 \mathrm{~m}$, Untuk satu sumur akan diisi dengan tiga buah buis beton, sehingga jumlah buis beton yang akan dibuat sebanyak 
9 buah. Pembuatan buis beton dilakukan di laboratorium Jurusan Teknik Sipil Politeknik Negeri Jakarta. Pada saat pembuatan buis beton juga dilakukan pengambilan sampel untuk uji kuat tekan dan penyerapan. Pembuatan buis beton dilaksanakan selama 9 hari. Prosedur pengecoran buis beton dapat dilihat pada Gambar 7.

d. Selanjutnya pada tanggal 10 Juli 2019 dilakukan pembuatan tutup sumur resapan. Tutupnya berbentuk persegi dengan ukuran 8 $\mathrm{cm} \times 60 \mathrm{~cm} \times 120 \mathrm{~cm}$. Dibuat sebanyak 6 buah, dapat dilihat pada Gambar 8 .

e. Setelah selesainya pembuatan buis beton dan tutupnya, tim PKM berdiskusi mengenai masalah pelaksanaan di lokasi. Hasil diskusi menetapkan kapan dimulianya pengangkutan buis beton dan tutupnya ke lokasi, penggalian, pemasangan buis beton sampai menjadi sumur resapan.

f. Pengangkutan buis beton dan tutupnya dilaksanakan pada tanggal 17 Juli 2019. Diangkut menggunakan truk engkel dengan tiga kali pengangkutan (lihat Gambar 9).

g. Pada tanggal 22 Juli 2019 dimulai penggalian di lokasi, yang dilaksanakan selama tiga hari. Penggalian dilakukan sampai kedalaman $2 \mathrm{~m}$ dengan diameter galian lebih kurang $125 \mathrm{~cm}$. Tanah hasil galian diangkut ke tempat lain.

h. Setelah penggalian selesai, Tim PKM merencanakan kegiatan yang akan dilaksanakan pada tanggal 27 Juli 2019. Kegiatan yang direncanakan adalah memasukkan buis beton ke dalam galian yang sudah dipersiapkan serta memasukkan ijuk dan batu pecah ke dalamnya. Kegiatan ini melibatkan warga dan beberapa orang mahasiswa serta beberapa orang dosen dari Jurusan Teknik Sipil. Buis beton dimasukkan menggunakan tackle dengan mengikatnya dengan tali tambang dan diturunkan secara perlahan. Satu demi satu buis beton masuk ke dalam lubang galian, prosesnya dapat dilihat pada Gambar 10.

i. Pekerjaan dilanjutkan dengan memasukkan ijuk dan batu pecah ukuran $20-30 \mathrm{~cm}$ ke dalam lubang yang gunanya agar air meresap ke dalam tanah menjadi lebih bersih. Selanjutnya dari drainase yang sudah ada dibuatkan saluran dari pipa PVC ukuran 4" ke dalam sumur resapan. Jika hujan turun cukup deras diharapkan air dari drainase dapat masuk ke dalam sumur resapan dan tidak meluap ke jalan. Pemasangan tutup dilakukan setelah semuanya selesai dilaksanakan. Pelaksanaan kegiatannya dapat dilihat pada Gambar 11.

j. Untuk meninjau kekuatan dari buis beton non pasir, Tim PKM melakukan pengujian kuat tekan. Pengujian dilakukan menggunakan alat uji kuat tekan yang ada di Laboratorium Jurusan Teknik Sipil Politeknik Negeri Jakarta. Pengujian dilakukan pada tiga buah silindaer beton non pasir. Berikut hasil pengujian disajikan dalam Tabel 1 .
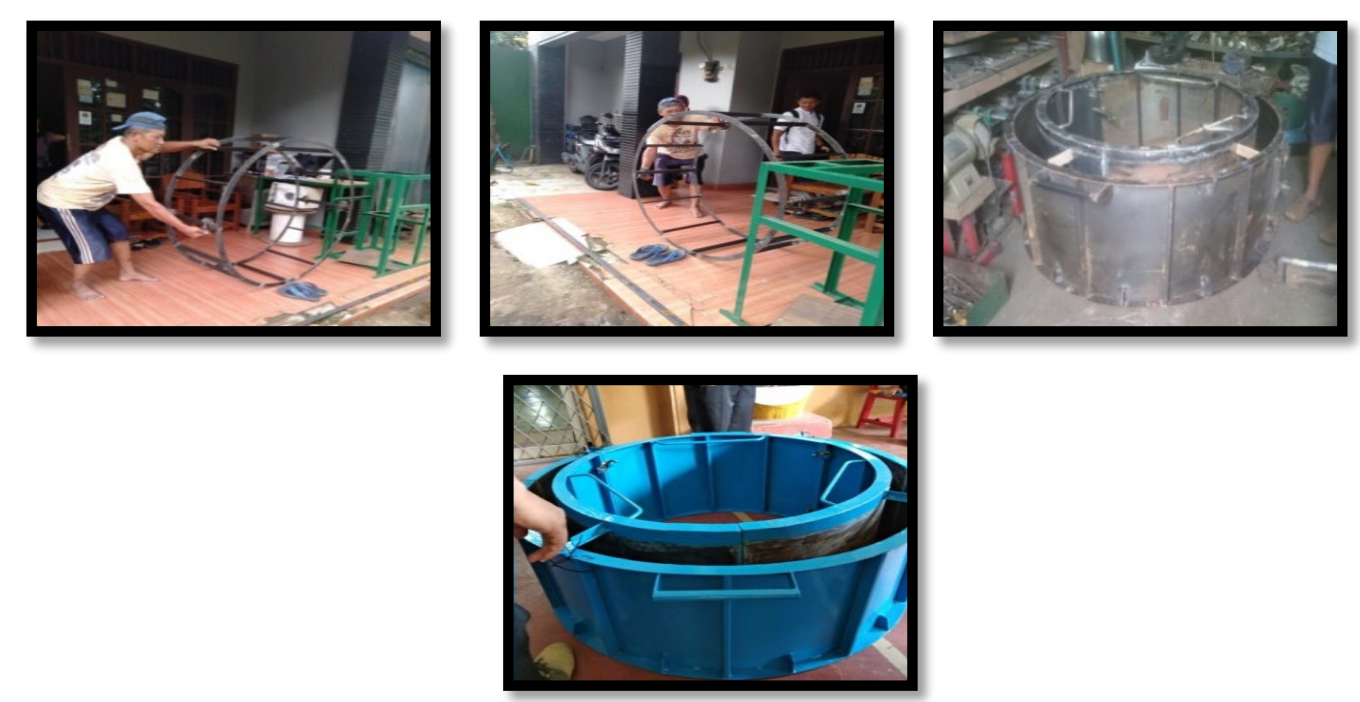

Gambar 6. Pembuatan Cetakan Buis Beton 

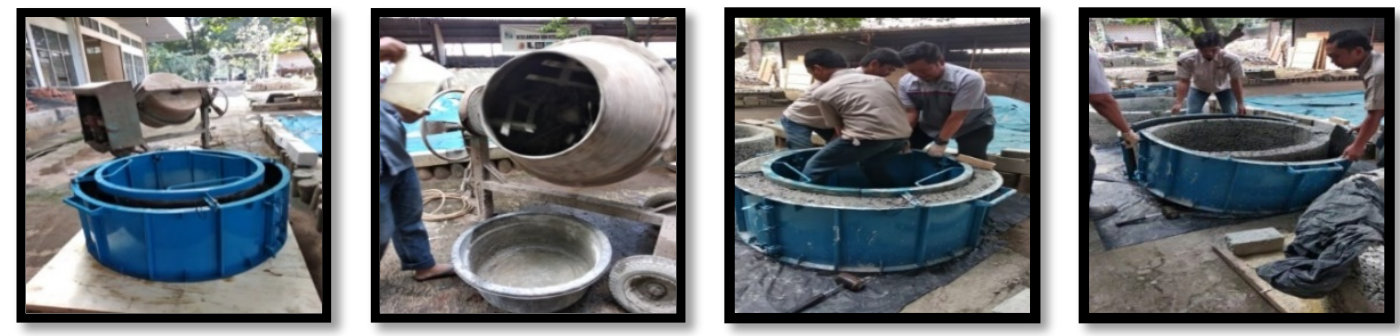

Gambar 7. Pengecoran Buis Beton dan Pembukaan Cetakan
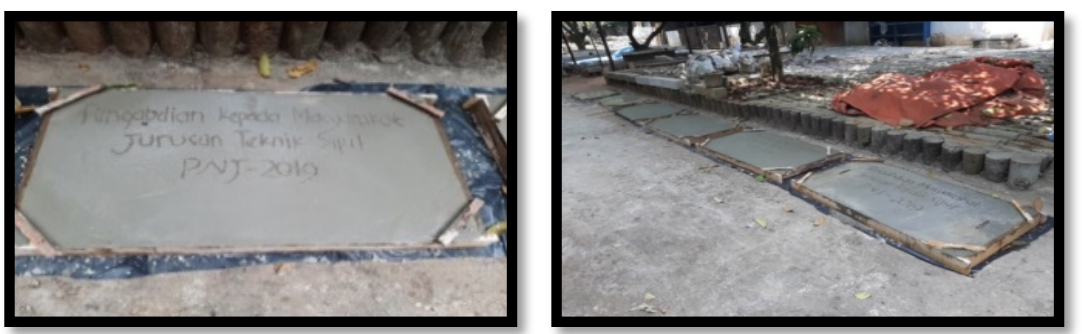

Gambar 8. Pengecoran Tutup Buis Beton
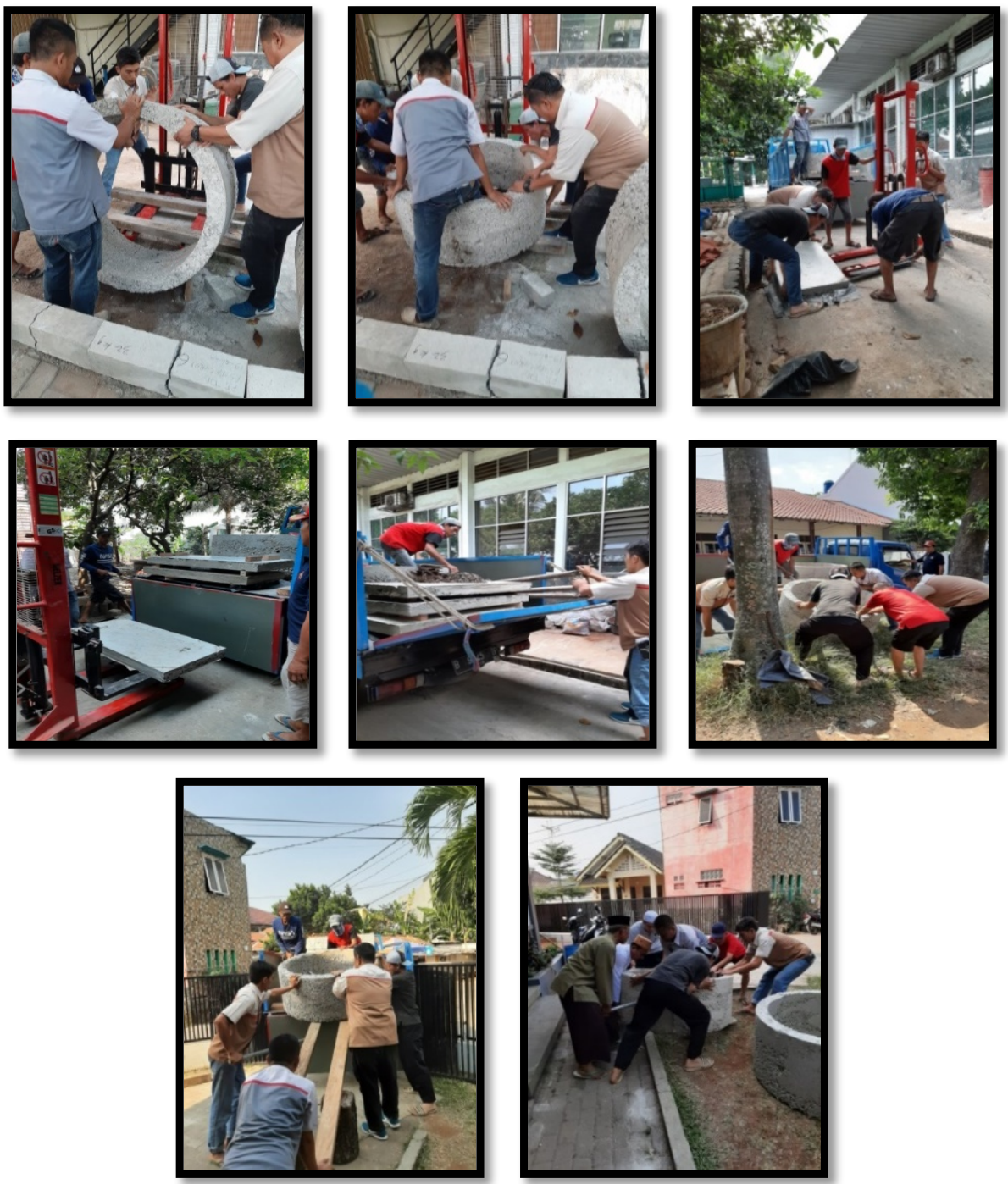

Gambar 9. Proses Pengangkutan Buis Beton dan Tutup ke Lokasi 

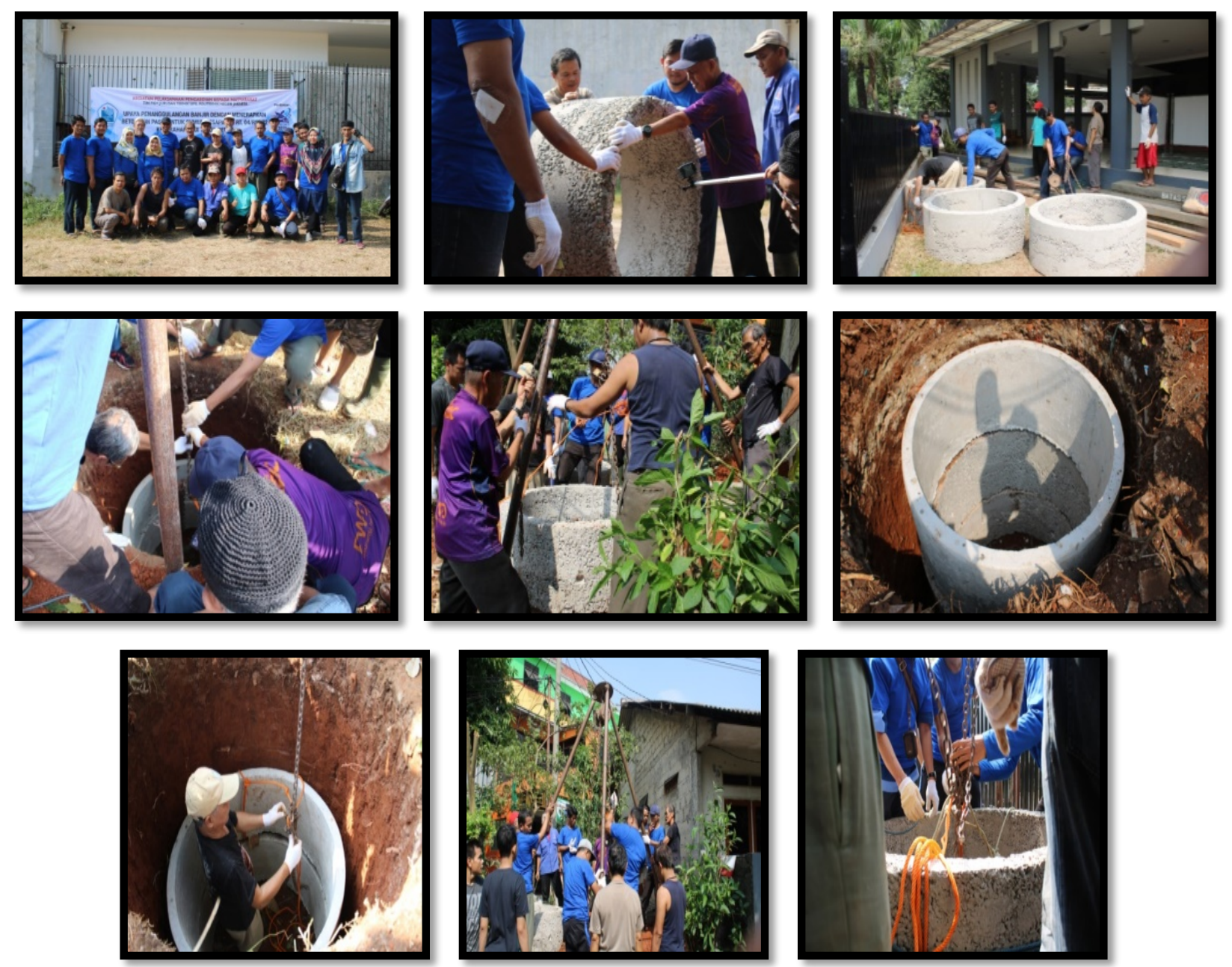

Gambar 10. Pelaksanaan Kegiatan Memasukkan Buis Beton
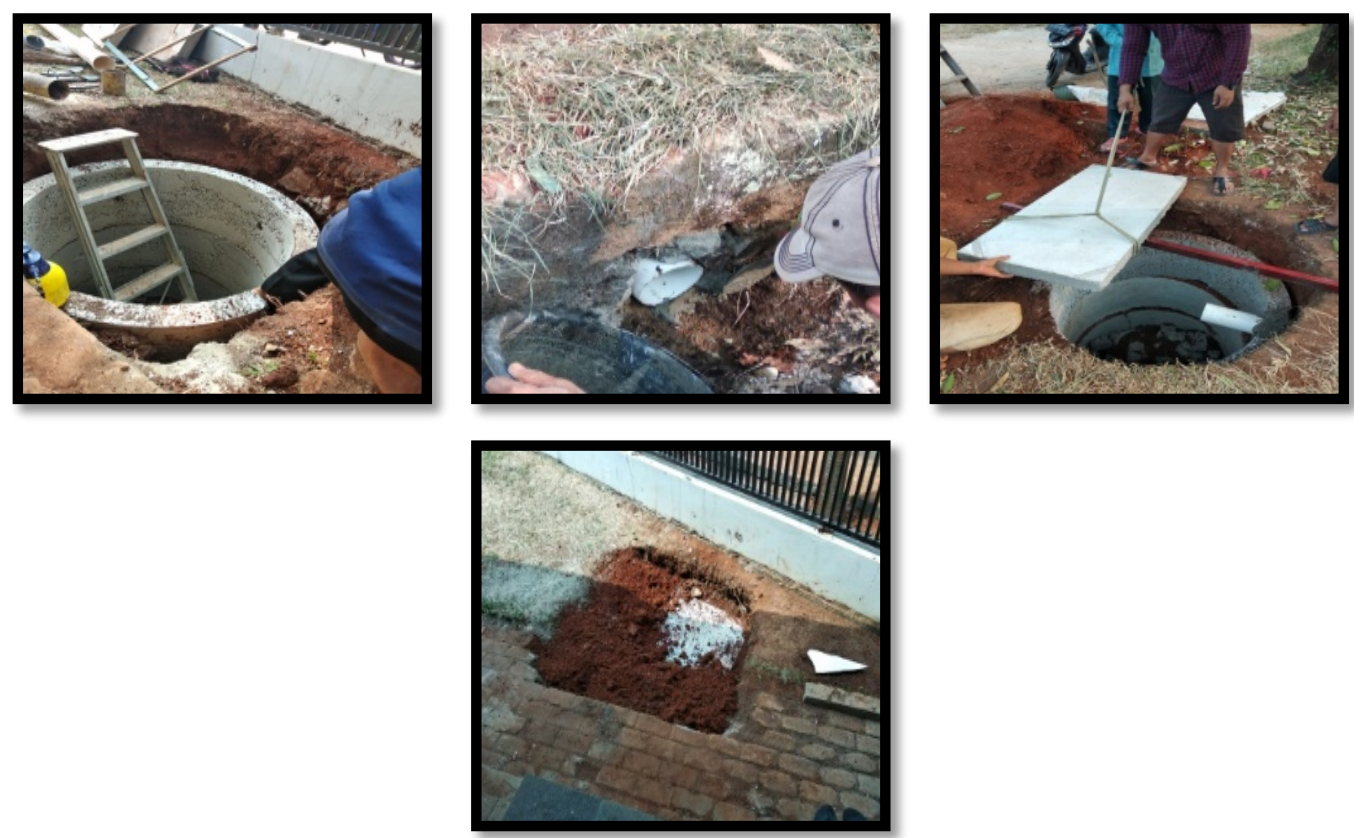

Gambar 11. Pembuatan Drainase dan Pemasangan Tutup 
Tabel 1. Hasil Pengujian Kuta Tekan Beton Non Pasir

\begin{tabular}{|c|c|c|c|c|c|}
\hline \multirow{2}{*}{ No. } & \multirow{2}{*}{$\begin{array}{l}\text { Berat } \\
(\mathrm{Kg})\end{array}$} & \multirow{2}{*}{$\begin{array}{l}\text { Berat } \\
\text { Isi } \\
\left(\mathrm{Kg} / \mathrm{m}^{3}\right)\end{array}$} & \multirow{2}{*}{$\begin{array}{l}\text { Beban } \\
\text { Maks } \\
(\mathrm{KN})\end{array}$} & \multicolumn{2}{|c|}{ Kuat Tekan } \\
\hline & & & & (MPa) & $\left(\mathrm{Kg} / \mathrm{cm}^{2}\right)$ \\
\hline 1 & 10,4 & 1962,73 & 85 & 4,81 & 48,10 \\
\hline 2 & 10,2 & 1924,98 & 92 & 5,21 & 52,09 \\
\hline 3 & 10,3 & 1943,85 & 78 & 4,42 & 44,16 \\
\hline \multicolumn{4}{|c|}{ Rata-Rata $=$} & 4,81 & 48,13 \\
\hline
\end{tabular}

Berdasarkan Tabel 1 terlihat bahwa nilai kuat tekan beton non pasir buis beton yang digunakan sebagai sumur resapan adalah 4,81 $\mathrm{MPa}$ atau 48,13 Kg/cm2. Hasil ini sesuai menurut ACI 522R-10 yang menyatakan bahwa beton non pasir memiliki kuat tekan sebesar 2,8 $-28 \mathrm{MPa}$.

\section{Kesimpulan}

Kegiatan Program Kemitraan Masyarakat (PKM) dengan judul Upaya Penanggulangan Banjir Dengan Menerapkan Beton Non Pasir Untuk Sumur Resapan Di Rt. 04/Rw. 02 Kelurahan Beji Timur Depok sudah selesai dilaksanakan. Tujuan dari kegiatan ini telah tercapai yaitu membuat sumur resapan yang digunakan untuk menanggulangi banjir dan juga untuk ketersediaan air tanah di lingkungan tersebut. Kegiatan ini melibatkan warga masyarakat yang sangat antusias membantu kegiatan ini. Ikutnya warga masyarakat dalam kegiatan ini diharapkan mereka dapat merasa ikut memiliki sumur resapan tersebut dan dapat memeliharanya. Karena sumur resapan itu juga harus dijaga dari sampah yang masuk lewat drainase, sehingga drainase harus dibersihkan secara berkala. Kegiatan ini juga melibatkan mahasiswa Jurusan Teknik Sipil Politeknik Negeri Jakarta agar mahasiswa dapat menambah wawasan bagaimana menerapkan suatu pekerjaan secara langsung di lapangan dan dalam melakukan pendekatan kepada masyarakat.

\section{Ucapan Terima Kasih}

Kami sebagai Tim pelaksana kegiatan PKM mengucapkan terima kasih kepada Kementerian Ristekdikti atas dukungan finansial pada kegiatan Program Kemitraan Masyarakat (PKM) ini yang disalurkan melalui P3M PNJ. Oleh sebab Kami sampaikan juga ucapan terima kasih kepada Kepala P3M PNJ. Apresiasi yang tinggi kepada Ketua RT 04/RW 02 beserta segenap warga yang sudah mendukung dan berpartisipasi aktif dalam kegiatan ini. Selain itu Kami juga berterima kasih atas bantuan tenaga, waktu, dan pikiran dari rekan-rekan Dosen, PLP, Mahasiswa, dan rekan yang ada di Laboratorium Jurusan Teknik Sipil Politeknik Negeri Jakarta.

\section{Daftar Pustaka}

[1] https://kelurahanbejitimurdepok.wordpress.com /profil-2/2-letak-geografis/

[2] https://id.wikipedia.org/wiki/Beji_Timur,_Beji, _Depok

[3] Suripin. 2004. Sistem Drainase yang Berkelanjutan. Yogyakarta (ID): Andi Offset.

[4] Arafat Y. 2008. Reduksi beban aliran drainase permukaan menggunakan sumur resapan. Jurnal SMARTek. 6(3): 144-153.

[5] Badan Standardisasi Nasional, 2002. Tata Cara Perencanaan Sumur Resapan Air Hujan untuk Lahan Pekarangan (SNI-03-24532002). Jakarta: BSN.

[6] Sinaga TR. 2017. Analisis pengaruh sumur resapan terhadap aliran permukaan di DAS mikro Cikardipa dengan metode simulasi SWAT [skripsi]. Bogor (ID): Fakultas Pertanian, Institut Pertanian Bogor

[7] Kusnaedi. 1996. Sumur Resapan untuk Pemukima Perkotaan dan Pedesaan. Jakarta (ID): Penebar Swadaya

[8] Mulyana R. 1998. Penentuan tipe konstruksi sumur resapan berdasarkan sifat-sifat fisik atanh dan kondisi sosial ekonomi masyarakat di kawasan puncak [tesis]. Bogor (ID): Institut Pertanian Bogor.

[9] Tjokrodimulyo, Kardiyono. 2009. Teknologi Beton. Biro Penerbit Teknik Sipil Universitas Gajah Mada

[10] ACI Committee 522, 2010, Report on Pervious Concrete (ACI 522R-10), American Concrete Institute, Farmington Hills, Michigan. 